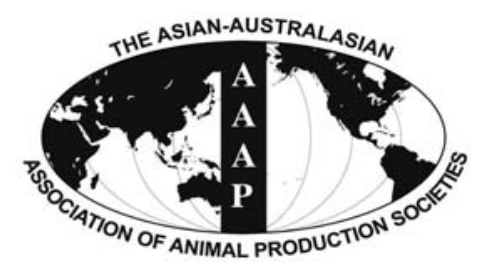

Asian-Aust. J. Anim. Sci.

Vol. 25, No. 2 : 240 - 247

February 2012

www.ajas.info

http://dx.doi.org/10.5713/ajas.2011.11304

\title{
Metabolisable Energy, In situ Rumen Degradation and In vitro Fermentation Characteristics of Linted Cottonseed Hulls, Delinted Cottonseed Hulls and Cottonseed Linter Residue
}

\author{
Y. K. Bo, H. J. Yang*, W. X. Wang, H. Liu ${ }^{1}$, G. Q. Wang ${ }^{1}$ and X. Yu ${ }^{1}$ \\ State Key Laboratory of Animal Nutrition, College of Animal Science and Technology, \\ China Agricultural University (CAU), Beijing 100193, China
}

\begin{abstract}
Dietary supplementation with conventional linted cottonseed hulls (LCSH) is a common practice in livestock production all over the world. However, supplementation with mechanically delinted cottonseed hulls (DCSH) and cottonseed linter residue (CLR) is uncommon. Cottonseed by-products, including LCSH, DCSH and CLR, were assessed by chemical analysis, an in situ nylon bag technique, an in vitro cumulative gas production technique and in vitro enzyme procedure. The crude protein (CP) content of CLR (302 g/kg dry matter (DM)) was approximately 3 times that of LCSH and 5 times that of DCSH. The crude fat content was approximately 3 times higher in CLR (269 g/kg DM) than in LCSH and 4 times higher than in DCSH. Neutral detergent fibre (311 g/kg $\mathrm{DM}$ ) and acid detergent fibre (243 g/kg DM) contents of CLR were less than half those of DCSH or LCSH. Metabolisable energy, estimated by in vitro gas production and chemical analyses, ranked as follows: CLR $(12.69 \mathrm{~kJ} / \mathrm{kg} \mathrm{DM})>\mathrm{LCSH}(7.32 \mathrm{~kJ} / \mathrm{kg} \mathrm{DM})>\mathrm{DCSH}$ $(5.82 \mathrm{~kJ} / \mathrm{kg} \mathrm{DM})$. The in situ degradation trial showed that the highest values of effective degradability of DM and CP were obtained for CLR $(\mathrm{p}<0.05)$. The in vitro disappearance of ruminal DM ranked as follows: CLR $>$ LCSH $>$ DCSH $(\mathrm{p}<0.05)$. The lowest digestibility was observed for DCSH with a two-step in vitro digestion procedure $(\mathrm{p}<0.05)$. The potential gas production in the batch cultures did not differ for any of the three cottonseed by-product feeds. The highest concentration of total volatile fatty acids was observed in CLR after a $72 \mathrm{~h}$ incubation $(\mathrm{p}<0.05)$. The molar portions of methane were similar between all three treatments, with an average gas production of 22\% (molar). The CLR contained a higher level of CP than did LCSH and DCSH, and CLR fermentation produced more propionate. The DCSH and LCSH had more NDF and ADF, which fermented into greater amounts of acetate. (Key Words : Cottonseed By-products, In situ Degradation, In vitro Fermentation)
\end{abstract}

\section{INTRODUCTION}

The Xinjiang Uygur autonomous region (province), located in the most northwest area of China, produces $95 \%$ of China's long lint cotton (Gossypium spp.). In 2010, the cotton cultivation area in Xinjiang was estimated at more than $10^{9}$ ha, with an annual yield of about 2.6 million tons (The Ministry of Agriculture of the People's Republic of China, 2010). After the cotton is harvested and ginned to remove the long lint fibres, the cottonseed by-products (CSBPs) become a readily available non-conventional feed resource for local livestock producers. Ginning typically

\footnotetext{
* Corresponding Author : H. J. Yang. Tel: +86-10-6273-3124, Fax: +86-10-6273-4859, E-mail: yang_hongjian@sina.com

${ }^{1}$ College of Animal Science, Xinjiang Agricultural University, Urumuqi 830052, China.

Received August 29, 2011; Accepted November 6, 2011
}

generates 100 to $120 \mathrm{~g}$ of cotton fibres per kg of harvested cotton (Moreira et al., 2004). The remainder is predominantly linted whole cottonseed, which has high levels of metabolizable energy, protein and effective degradable fiber. In developed countries, linted cottonseed is used to replace protein, forage, or grain in ruminant diets (Harvatine et al., 2002; Bertrand, 2005).

Typically, linted cottonseed is run in one direction through a fine set of gin saws to remove short cotton fibres. This leaves mechanically delinted whole cottonseed, which is then usually crushed into a meal and oil fraction. The oil removal process (solvent extraction) is similar to that used in the soybean, flax and canola crushing industry. The meal has been well accepted as a protein supplement for dairy, other livestock and poultry. Mechanically delinted whole cottonseed can also be fed directly to ruminants and is preferred by feed manufacturing firms because of its ease of mechanical handing. 
Linted whole cottonseed can also be delinted by sulphuric acid treatment, which leaves a completely slick seed with no usable short fibres. This slick seed is used as a seed stock because it flows well in mechanical cottonseed planters. Acid delinted whole cottonseed can also be fed to livestock, but it is often unpalatable due to odours associated with sulphuric acid. Linted whole cottonseed can also be dehulled, which results in kernels and 250 to 380 $\mathrm{g} / \mathrm{kg}$ of linted cottonseed hulls (Kromer, 1977). The kernels are mechanically pressed or chemically extracted to produce cottonseed oil, with yields of 150 to $200 \mathrm{~g}$ of oil and 470 to $500 \mathrm{~g}$ of cottonseed kernel meal per kg of whole linted cottonseed (Cherry, 1983). It is still a luxury to use linted whole cottonseed or delinted whole cottonseed directly in ruminant diets in Xinjiang or other places in China, but the linted cottonseed hulls are routinely used as either roughage for cattle or as a main ingredient of a culture medium for edible mushrooms (Hale et al., 1963).

The long cotton linters that are retained on the hulls, when incubated in sacco and in vitro for periods varying from 12 to $120 \mathrm{~h}$, show a delayed digestibility after colonization. This is due to the highly crystalline structure of long cotton fibres, which hydrate slowly. This lag in cotton long fibre digestion would be expected to increase the pool size of undigested fibre in ruminants fed whole linted cottonseed (Palmquist, 1995). No literature has yet been published regarding the nutritive value of short cotton linters.

In general, linted cottonseed hulls have a low crude protein content ranging from 40 to $120 \mathrm{~g} / \mathrm{kg}$ dry matter (DM), high neutral detergent fibre ranging from 735 to 890 $\mathrm{g} / \mathrm{kg} \mathrm{DM}$ and a large proportion of acid detergent lignin is negatively correlated with digestibility of DM and fibre (Hsu et al., 1987; Garleb et al., 1988). However, conventional linted cottonseed hulls, when added to low fibre diets, are believed to have greater feeding value than their digestibility indicates (Coppock et al., 1987). Linted cottonseed hulls are well accepted by livestock producers in Xinjiang, on those occasions when income from mushrooms is low and linted cottonseed hulls material is readily available.

Cottonseed short linter residue (CLR) is a material that consists of cotton short linters arising from a fine cottonseed hull delinting process, together with kernels culled before cottonseed oil extraction. No experimental data are yet available to compare feeding of linted versus CLR. Compared to conventional linted cottonseed hulls, delinted cottonseed hulls and CLR have not been as readily accepted by local farmers, due largely to a lack of knowledge regarding their nutritive value. The objective of the present study was to assess the CLR cottonseed by-product in terms of nutrient composition, metabolizable energy content, in situ ruminal degradation and in vitro fermentation characteristics.

\section{MATERIALS AND METHODS}

\section{Cottonseed by-products}

The locations of Changji $\left(87^{\circ} 31^{\prime} \mathrm{E}, 44^{\circ} 05^{\prime} \mathrm{N}\right)$, Shihezi $\left(85^{\circ} 94^{\prime} \mathrm{E}, 37^{\circ} 49^{\prime} \mathrm{N}\right)$ and Kuitun $\left(84^{\circ} 89^{\prime} \mathrm{E}, 44^{\circ} 45^{\prime} \mathrm{N}\right)$ are important sites in the northern region of Tianshan Mountain in the Xinjiang Uygur Autonomous Region of China for the production of long lint cotton (Gossypium spp.). In each location, representative samples of lint cottonseed hull (LCSH), delinted cottonseed hull (DCSH) and CLR were collected from two cottonseed oil-extracting plants. All samples were dried at $65^{\circ} \mathrm{C}$ for $24 \mathrm{~h}$ in a forced air oven, ground to pass through a $1.18-\mathrm{mm}$ screen and stored prior to chemical analyses, in situ degradation trials and in vitro batch culture trials.

\section{Animals and feeding}

Three lactating Holstein dairy cows, each fitted with a ruminal cannula (Bar Diamond Inc., Parma, Idaho, USA), were fed $25 \mathrm{~kg}$ of a total mixed ration with a DM content of $520 \mathrm{~g} / \mathrm{kg}$, divided in equal portions and offered daily at 06:00 and 18:00. The animals had free access to water. The ration, on an as-fed basis, consisted of $83 \mathrm{~g}$ alfalfa hay, 167 g Chinese wild rye grass hay, 250 g corn silage, 267 g maize meal, $68.9 \mathrm{~g}$ wheat bran, $137.5 \mathrm{~g}$ soybean meal, 11.1 g limestone, $6.1 \mathrm{~g}$ dicalcium phosphate, $4.4 \mathrm{~g}$ sodium chloride and $5.0 \mathrm{~g}$ commercial vitamin and trace mineral premix (per kg DM). The net energy for lactation and the crude protein (CP) content (per kg of the ration as fed) were 6.17 MJ and $138.7 \mathrm{~g}$, respectively.

\section{In situ degradation trial}

Nylon bags (12 cm $\times 8 \mathrm{~cm}$ i.d. and $48 \mu \mathrm{m}$ of pore size) were filled with $3 \mathrm{~g}$ cottonseed material sample (1.18-mm) and incubated in the rumen for periods of 2, 4, 8, 16, 24, 48 and $72 \mathrm{~h}$. Duplicate bags were incubated in each animal for each incubation time. All bags were placed in the rumen simultaneously, just before the animals were offered their first meal of the morning. After removal from the incubation, the bags were washed with tap water for 15 min until the washing water was clear. The same procedure was used for two series of two bags to obtain the $0 \mathrm{~h}$ value. For each animal and incubation time, bags were dried at $65^{\circ} \mathrm{C}$ for $48 \mathrm{~h}$ and analysed for DM and nitrogen (N).

\section{In vitro gas production trial}

A total of $500 \mathrm{mg}$ of each cottonseed material feeds (1.18-mm) was placed into $120 \mathrm{ml}$ glass bottles containing $25 \mathrm{ml}$ of a medium (pH 6.8; Menke and Steingass, 1988) 
containing rumen liquor that had been filtered through 4 layers of cheesecloth. The rumen liquor was collected from the animals one hour after the morning feeding. The entire batch culture was conducted and repeated in five runs.

In the automated system, 5 bottles were set up for each cottonseed feed per run. The bottles were purged with $\mathrm{N}_{2}$ for $5 \mathrm{~s}$, sealed with butyl rubber stoppers and Hungate's screw caps, connected to the gas inlets of an automated gas production recording system and incubated at $39^{\circ} \mathrm{C}$, as described by Zhang and Yang (2011). A $3.0 \mathrm{ml}$ calibrated cumulative gas production for each vent was automatically recorded with a differential pressure switch (pressure range: 20 to 300 pa, Huba Control Inc., USA) when the pressure inside the bottle had reached 100 pa. Cumulative gas production in each bottle was recorded against time of incubation.

In the manually operated system, extra 5 bottles of the same size, containing the same medium, inoculum and cottonseed material as in the automated system trial were connected to pre-emptied airbags and incubated at $39^{\circ} \mathrm{C}$. This allowed collection of whole fermentation gas end products for later analysis of $\mathrm{CO}_{2}, \mathrm{CH}_{4}$ and $\mathrm{H}_{2}$ composition. In both incubation systems, five bottles without any cottonseed substrate were included in each run as blanks and, if necessary, to correct for variation between the runs caused by differences in the rumen fluid inoculum collected at different periods.

After $72 \mathrm{~h}$ incubation, three $1.0 \mathrm{ml}$ gas samples were removed from the airbags used in the manual incubation system and were immediately analysed for $\mathrm{CO}_{2}, \mathrm{CH}_{4}$ and $\mathrm{H}_{2}$ concentration using the gas chromatographic method of Zhang and Yang (2011). For both the automatic and manual systems, $1 \mathrm{ml}$ of the culture fluids from each bottle was mixed with $0.3 \mathrm{ml}$ of $250 \mathrm{~g} / \mathrm{L}$ meta-phosphoric acid solution, incubated for $30 \mathrm{~min}$ and then centrifuged at $10,000 \times \mathrm{g}$ at $4^{\circ} \mathrm{C}$ for $15 \mathrm{~min}$. Ammonia $\mathrm{N}$ concentration in the supernatants was then measured by spectrophotometry (Verdouw et al., 1978), and the concentrations of volatile fatty acids (VFA), including acetate, propionate, butyrate, iso-butyrate, valerate and iso-valerate, were measured by the gas chromatographic method described by Zhang and Yang (2011).

The biomass cultures remaining in the bottles were centrifuged at $4,000 \times \mathrm{g}$ at $4^{\circ} \mathrm{C}$ for $30 \mathrm{~min}$, and the pellets were dried at $105^{\circ} \mathrm{C}$. In vitro dry matter disappearance (IVDMD1) was calculated as the loss in DM, represented as the difference between the incubated DM and residual DM, corrected by blanks.

\section{Two step in vitro DM digestion trial}

Following the method of Tilley and Terry (1963), 500 $\mathrm{mg}$ of CSBP samples $(1.18 \mathrm{~mm})$ were incubated at $39^{\circ} \mathrm{C}$ for $24 \mathrm{~h}$ with $50 \mathrm{ml}$ McDougall's buffer (containing $9.8 \mathrm{~g}$
$\mathrm{NaHCO}_{3}, 2.77 \mathrm{~g} \mathrm{Na}_{2} \mathrm{HPO}_{4}, 0.57 \mathrm{~g} \mathrm{KCl}, 0.47 \mathrm{~g} \mathrm{NaCl}, 0.12 \mathrm{~g}$ $\mathrm{MgSO}_{4} \cdot 7 \mathrm{H}_{2} \mathrm{O}$, and $0.16 \mathrm{~g} \mathrm{CaCl} 2 \mathrm{H}_{2} \mathrm{O}$ per litre) and $25 \mathrm{ml}$ filtered rumen liquor, followed by a $24 \mathrm{~h}$ acid-pepsin digestion at $39^{\circ} \mathrm{C}$. Five blanks without CSBP sample were also run. The biomass cultures were centrifuged at 4,000 $\times \mathrm{g}$ for $20 \mathrm{~min}$ and the pellets were dried at $105^{\circ} \mathrm{C}$ for the determination of the residual DM. The two-step in vitro DM disappearance (IVDMD2) was calculated as the difference between the original incubated DM and the residual DM, corrected by the blank readings. All analyses were performed using five replicates for each feed.

\section{Chemical analyses}

For the representative CSBP samples and the residues used in the trials, the chemical analysis methods of AOAC (1999) were followed to determine the DM (method ID 934.15), ether extract (EE, method ID 920.30), $\mathrm{CP}(\mathrm{N} \times 6.25$; method ID 984.13), calcium (method ID 968.08) and total phosphorous (method ID 995.11) levels. Neutral detergent fibre (NDFom; not assayed with a heat stable amylase) and acid detergent fibre (ADFom) were analysed following the method of Van Soest et al. (1991) and the data were expressed without residual ash.

\section{Biometric analyses}

The ruminal disappearance $(\mathrm{Y})$ of $\mathrm{DM}$ and $\mathrm{CP}$ at time (t) was fitted to an exponential model by an iterative regression analysis (Ørskov and McDonald, 1979) using the nonlinear (NLIN) procedure of SAS (1999). The model is described by Eq. (1):

$$
Y=a+b \times\left(1-e^{-c \times x}\right)
$$

where ' $e$ ' is the base of a natural logarithm; the constant ' $a$ ' represents the soluble and very rapidly degradable component and ' $b$ ' represents the insoluble, but potentially degradable, component, which has a constant degradation rate (c) per unit time.

The effective degradabilities (EDs) of DM and CP were then estimated using Eq. (2) (Ørskov and McDonald 1979):

$$
E D=a+\frac{b \times c}{c+k}
$$

where ' $k$ ' refers to the fractional outflow rate. A value of $0.06 / \mathrm{h}$ was assumed for $\mathrm{k}$, as suggested in the literature (INRA, 1988).

The cumulative gas production $(\mathrm{Y}, \mathrm{ml} / \mathrm{g} \mathrm{DM})$ at time $(\mathrm{t})$ was fitted to the same exponential model as in Eq. (1). In this model, the constant ' $a$ ' represents gas production of the soluble and very rapidly degradable nutrients, while 'b' represents gas production of the insoluble but potentially degradable nutrients that generate fermentation gases at a 
constant fractional rate (c) per unit time. A sum of parameters ' $a$ ' and 'b' was assumed to represent maximum gas production at infinite time because parameters ' $a$ ' and 'b' cannot be measured separately in vitro.

The in vitro $24 \mathrm{~h}$ gas production from $200 \mathrm{mg}$ DM of the CSBPs was extrapolated according to the gas production Eq. (1). Metabolisable energy (ME) of CSBPs was calculated with the empirical equations noted in Table 2. Data for ME for three CSBPs were analysed using a general linear model procedure of SAS (1999), and the means of ME between CSBPs were compared using Duncan's test.

Individual VFAs were summed to give a total VFA concentration. Iso-butyrate and iso-valerate were summed as the branched chain VFAs (BCVFA). The ratio of nonglucogenic to glucogenic acids (NGR; Ørskov, 1975) was calculated using Eq. (3):

$$
N G R=\frac{\text { Acetate }+2 \times \text { Butyrate }+ \text { Valerate }}{\text { Propionate }+ \text { Valerate }}
$$

For comparison between CSBPs, data for the in situ degradation (animal replicate: $\mathrm{N}=3$ ) and in vitro batch culture trials (batch replicate: $\mathrm{N}=5$ ) were subjected to oneway analysis of variance. On detection of overall significant differences by analysis of variance, multiple comparisons among least square means were carried out by Duncan's new multiple range test. The means and standard errors of least square means were reported in the result tables. Significance was declared at $\mathrm{p}<0.05$, unless otherwise noted.

\section{RESULTS}

\section{Nutrient composition and estimated metabolisable energy}

Table 1 shows the $\mathrm{CP}$ content ranking to be as follows: CLR $>$ LCSH $>$ DCSH $(p<0.05)$. The NDFom and ADFom contents ranking was as follows: DCSH $>$ LCSH $>$ CLR $(p<0.05)$; and the EE content ranking was CLR $>$ LCSH $>$ DCSH $(p<0.05)$. The calcium content was higher in DCSH

Table 1. Chemical composition (g/kg DM) of delinted cottonseed hulls (DCSH), linted cottonseed hulls (LCSH) and cottonseed linter residue (CLR)

\begin{tabular}{lrrrl}
\hline & DCSH & LCSH & CLR & SEM \\
\hline Crude protein & $62.2^{\mathrm{c}}$ & $108.8^{\mathrm{b}}$ & $302.2^{\mathrm{a}}$ & 5.7 \\
Ether extract & $54.8^{\mathrm{c}}$ & $81.3^{\mathrm{b}}$ & $268.7^{\mathrm{a}}$ & 6.6 \\
NDFom $^{\mathrm{a}}$ & $829.4^{\mathrm{a}}$ & $716.4^{\mathrm{b}}$ & $311.4^{\mathrm{c}}$ & 7.4 \\
ADFom $^{\mathrm{b}}$ & $565.6^{\mathrm{a}}$ & $464.1^{\mathrm{b}}$ & $242.9^{\mathrm{c}}$ & 6.3 \\
Calcium $_{\text {Phosphorus }}$ & $0.9^{\mathrm{a}}$ & $0.8^{\mathrm{a}}$ & $0.6^{\mathrm{b}}$ & 0.1 \\
\hline
\end{tabular}

Means in a row without a common superscript differ $(\mathrm{p}<0.05, \mathrm{~N}=5)$.

${ }^{\text {a }}$ Neutral detergent fibre content expressed exclusive of residual ash.

${ }^{\mathrm{b}}$ Acid detergent fibre content expressed exclusive of residual ash.
Table 2. Metabolisable energy (ME) of delinted cottonseed hulls (DCSH), linted cottonseed hulls (LCSH) and cottonseed linter residue (CLR) estimated by in vitro ruminal gas production and chemical composition

\begin{tabular}{lcccc}
\hline & DCSH & LCSH & CLR & SEM \\
\hline ME (kJ/kg DM) & $6.06^{\mathrm{c}}$ & $7.14^{\mathrm{b}}$ & $13.29^{\mathrm{a}}$ & 0.601
\end{tabular}

Means in a row without a common superscript differ $(\mathrm{p}<0.05, \mathrm{~N}=5$ ).

In the table, the equation to estimate metabolizable energy is as follows: $\mathrm{ME}=146 \times \mathrm{GP}_{24}+7 \times \mathrm{CP}+22.4 \times \mathrm{EE}+1,242$ (Lee et al., 1991) where $\mathrm{CP}$ and EE represent crude protein and ether extractable contents, with units of $\mathrm{g} / \mathrm{kg} \mathrm{DM}$, while $\mathrm{GP}_{24}$ represents an extrapolated gas production with units of $\mathrm{ml} / 200 \mathrm{mg}$ DM for the fermentation time of up to $24 \mathrm{~h}$.

and LCSH than in CLR feeds $(\mathrm{p}<0.05)$. Total phosphorus content ranking was as follows: CLR $>$ LCSH $>$ DCSH $(\mathrm{p}<0.05)$. As shown in Table 2, ME content ranked as follows: $\mathrm{CLR}>\mathrm{LCSH}>\mathrm{DCSH}(\mathrm{p}<0.05)$.

\section{In situ DM and CP degradation kinetics}

For the DM degradation kinetics shown in Table 3, the ' $a$ ' value ranking was CLR $>$ LCSH $>$ DCSH $(p<0.05)$. The ' $b$ ' values of these CSBPs ranked as follows: DCSH> LCSH $>$ CLR $(p<0.05)$. The degradation rate ' $c$ ' ranking was CLR $>$ LCSH $>$ DCSH $(p<0.05)$. Consequently, the highest value of ED was found for CLR, followed by LCSH and DCSH in that order $(\mathrm{p}<0.05)$.

For the CP degradation kinetics shown in Table 3, a high value of parameter ' $a$ ' occurred for CLR $(p<0.05)$, whereas no difference was noted between DCSH and LCSH. Both the parameters ' $b$ ' and ' $c$ ' ranked as CLR>LCSH> DCSH $(p<0.05)$. Consequently, the ED ranked as follows: CLR $>$ LCSH $>$ DCSH $(\mathrm{p}<0.05)$.

Table 3. In situ dry matter and crude protein degradation kinetics of delinted cottonseed hulls (DCSH), linted cottonseed hulls (LCSH) and cottonseed linter residue (CLR)

\begin{tabular}{lllll}
\hline Items & DCSH & LCSH & CLR & SEM \\
\hline Dry matter & & & & \\
a & $0.04^{\mathrm{c}}$ & $0.05^{\mathrm{b}}$ & $0.14^{\mathrm{a}}$ & 0.002 \\
$\mathrm{~b}$ & $0.95^{\mathrm{a}}$ & $0.77^{\mathrm{b}}$ & $0.50^{\mathrm{c}}$ & 0.047 \\
c & $0.005^{\mathrm{c}}$ & $0.014^{\mathrm{b}}$ & $0.049^{\mathrm{a}}$ & 0.0024 \\
ED & $0.12^{\mathrm{c}}$ & $0.18^{\mathrm{b}}$ & $0.36^{\mathrm{a}}$ & 0.005 \\
Crude protein & & & & \\
a & $0.03^{\mathrm{b}}$ & $0.03^{\mathrm{b}}$ & $0.16^{\mathrm{a}}$ & 0.029 \\
b & $0.37^{\mathrm{c}}$ & $0.44^{\mathrm{b}}$ & $0.64^{\mathrm{a}}$ & 0.063 \\
c & $0.021^{\mathrm{c}}$ & $0.038^{\mathrm{b}}$ & $0.078^{\mathrm{a}}$ & 0.0115 \\
ED & $0.11^{\mathrm{c}}$ & $0.17^{\mathrm{b}}$ & $0.52^{\mathrm{a}}$ & 0.041 \\
\hline
\end{tabular}

Means in a row without a common superscript differ $(\mathrm{p}<0.05, \mathrm{~N}=3)$. In the table, item ' $a$ ' represents the soluble and very rapidly degradable nutrient; item ' $b$ ' represents the insoluble, but potentially degradable nutrient, which is degraded at a constant fractional rate (c, /h); and item ED is effective degradation in the rumen. 
In vitro dry matter digestibility and fermentation characteristics

As shown in Table 4, the values for the one-step measured IVDMD1 ranked as follows: CLR>LCSH> DCSH $(p<0.05)$. No differences were observed for the values for the two-step measured IVDMD2 obtained for $\mathrm{LCSH}$ and CLR. The lowest value of IVDMD2 was observed for DCSH $(\mathrm{p}<0.05)$.

Ammonia $\mathrm{N}$ concentration showed no differences between LCSH and CLR, and the lowest ammonia $\mathrm{N}$ concentration was found for DCSH $(\mathrm{p}<0.05)$. The highest means for total VFA concentration and molar propionate proportion were found for CLR $(\mathrm{p}<0.05)$. No difference was found between LCSH and CLR. Molar proportions of acetate, butyrate, valerate and BCVFA were similar among the three CSBPs, but molar propionate proportion ranking was CLR $>$ LCSH $>$ DCSH $(p<0.05)$. The lowest value of NGR occurred with CLR $(\mathrm{p}<0.05)$, and no difference for NGR was noted between DCSH and LCSH.

The maximum gas production 'a+b' value was similar between CLR and LCSH, but their means were greater than

Table 4. In vitro dry matter digestibility and fermentation characteristics of delinted cottonseed hulls (DCSH), linted cottonseed hulls (LCSH) and cottonseed linter residue (CLR) after $72 \mathrm{~h}$ incubation

\begin{tabular}{|c|c|c|c|c|}
\hline & DCSH & $\mathrm{LCSH}$ & CLR & SEM \\
\hline IVDMD1 & $0.16^{\mathrm{c}}$ & $0.32^{\mathrm{b}}$ & $0.37^{\mathrm{a}}$ & 0.008 \\
\hline IVDMD2 & $0.30^{\mathrm{b}}$ & $0.53^{\mathrm{a}}$ & $0.64^{\mathrm{a}}$ & 0.051 \\
\hline Ammonia $\mathrm{N}(\mathrm{mM})$ & $10.6^{\mathrm{b}}$ & $15.3^{\mathrm{a}}$ & $14.5^{\mathrm{a}}$ & 1.33 \\
\hline Total VFA (mM) & $74.0^{\mathrm{b}}$ & $89.7^{\mathrm{a}}$ & $103.7^{\mathrm{a}}$ & 4.86 \\
\hline \multicolumn{5}{|c|}{ VFA pattern (\%, molar) } \\
\hline Acetate & 62.5 & 60.3 & 56.3 & 4.54 \\
\hline Propionate & $21.2^{\mathrm{b}}$ & $23.6^{\mathrm{b}}$ & $30.4^{\mathrm{a}}$ & 1.35 \\
\hline Butyrate & 11.2 & 11.7 & 11.3 & 0.93 \\
\hline Valerate & 2.22 & 2.23 & 2.72 & 0.262 \\
\hline BCVFA & 2.71 & 2.71 & 3.04 & 0.283 \\
\hline NGR & $3.7^{\mathrm{a}}$ & $3.7^{\mathrm{a}}$ & $2.4^{\mathrm{b}}$ & 0.51 \\
\hline \multicolumn{5}{|c|}{ Kinetic gas production } \\
\hline a+b (ml/g DM) & $127.1^{\mathrm{b}}$ & $148.8^{\mathrm{a}}$ & $153.3^{\mathrm{a}}$ & 10.64 \\
\hline $\mathrm{c}(/ \mathrm{h})$ & $0.050^{\mathrm{C}}$ & $0.124^{\mathrm{b}}$ & $0.171^{\mathrm{a}}$ & 0.0067 \\
\hline \multicolumn{5}{|c|}{ Fermentation gas pattern (\%, molar) } \\
\hline $\mathrm{CO}_{2}$ & 79.5 & 74.7 & 82.3 & 2.84 \\
\hline $\mathrm{CH}_{4}$ & 23.5 & 25.0 & 17.5 & 3.15 \\
\hline $\mathrm{H}_{2}$ & 0.09 & 0.10 & 0.14 & 0.006 \\
\hline
\end{tabular}

Means in a row without a common superscript differ $(\mathrm{p}<0.05, \mathrm{~N}=5)$.

In the table, IVDMD1 and IVDMD2 represent in vitro dry matter disappearance measured by the one-step and the two-step methods, respectively; VFA is volatile fatty acids; BCVFA is branch-chained volatile fatty acids; NGR is the ratio of non-glucogenic to glucogenic acids; 'a' is the gas production of soluble and very rapidly degradable portion, 'b' represents the gas production of insoluble, but potentially degradable nutrient, which yields fermentation gases at a constant fractional rate (c, /h). the mean for DCSH $(\mathrm{p}<0.05)$. The gas production rate ' $\mathrm{c}$ ' value ranked as follows: $\mathrm{CLR}>\mathrm{LCSH}>\mathrm{DCSH}(\mathrm{p}<0.05)$. Molar proportions of $\mathrm{CO}_{2}, \mathrm{CH}_{4}$ and $\mathrm{H}_{2}$ did not statistically differ among the tested CSBPs.

\section{DISCUSSION}

\section{Nutrient composition of the CSBPs}

Many agricultural residues are poorly digested by ruminants because of their high content of cell wall materials. Physical and chemical methods are often used to break down the lignocellulosic materials of some agricultural residues and thereby improve the feeding value of crop residues such as stalks or straws. Oltjen et al. (1977) found that cottonseed hulls were more readily consumed (3.1\% of body weight (BW)) than were chopped barley straw $(2.0 \%$ of $\mathrm{BW})$ or corn stover $(1.4 \%$ of $\mathrm{BW})$. In the present study, the CP contents of DCSH and LCSH were close to literature values reported for the lower limit (40 g/kg DM) and upper limit (124 g/kg DM), respectively, for cottonseed hulls (Hsu, 1987; Garleb, 1988). The lower CP and higher fibre contents seen in DCSH compared to LCSH may be explained by the short delinting process, which might remove hull-associated protein, and the removal of the protein free short linters. The CP content in DCSH was somewhat higher than that reported for wheat straw (52 g/kg DM; Chriyaa, 1997) and the CP content of LCSH was similar to that reported for tall fescue and soybean stover and hulls (National Research Council (NRC), 1989).

The CLR product was actually a mixture of short linter dust and culled cottonseed kernels discarded in the process of cottonseed extraction. The exact ratio of short linter waste to culled cottonseed kernels was not determined in the present study. The CLR had a high CP content (302.2 $\mathrm{g} / \mathrm{kg} \mathrm{DM}$ ), close to that of different varieties of cottonseed hulls (230 to $303 \mathrm{~g} / \mathrm{kg} \mathrm{DM}$ ) reported in the literature (Fadel, 1999; Robinson et al., 2001). The EE content of CLR (268.7 $\mathrm{g} / \mathrm{kg} \mathrm{DM}$ ) was close to that of delinted cottonseeds reviewed by Coppock et al. (1987) and greater than that of whole cottonseeds reported by Sullivan et al. (1993) and NRC (1989). These results indicated that a substantial portion of culled cottonseed kernels had been mixed with short linter dust to result in the CLR cottonseed by-product. The calcium content was comparable among the three CSBPs, but CLR had substantial phosphorus content.

\section{Metabolisable energy prediction of CSBPs}

In the present study, the ME value for CLR was greater than that determined for LCSH and almost twice that found for DCSH. The ME content of CLR was close to previously estimated ME contents of whole cottonseed and soybean meal (Getachew et al., 2002; Granger et al., 2010) and was at least $20 \%$ higher than that reported for corn silage, alfalfa 
hay and fresh napier grass (Lee et al., 2000). A greater ME content was observed for LCSH than for DCSH and was comparable to the ME value determined for dehydrated alfalfa meal (NRC, 1989).

\section{In situ and in vitro degradability of CSBPs}

In the last few decades, several high energy, high fibre alternative feeds have been categorized as either concentrates or forages. The concentrate group includes linted whole cottonseed, dried distillers grains and dried brewers grains, whereas the forage group includes, beet pulp, soy hulls, cottonseed hulls and others. These feeds can be economical sources of fibre, energy, indigestible and degradable protein and other nutrients. In the present paper, the in situ and in vitro trials indicated a greater digestibility and fermentability of CLR than was seen for either LCSH or DCSH. This suggests that the ruminal degradation rate for the CSBPs should correlate positively with the ratio of kernel content to short linter. In the present study, the in situ DM and CP kinetic parameter ' $c$ ' and the ED of CLR were higher than for the other two feeds, which suggested that CLR had a higher degradable kernel CP content in CLR than was present in the other two CSBPs.

Moreira et al. (2004) reported that mechanically delinted whole cottonseed was just as effective a feed as linted whole cottonseed, as determined by dairy cow milk yield and milk composition. However, a negative interaction was noted when a combination of cottonseed hulls and cotton long linter were fed to ruminants (Coppock et al., 1985; Sullivan et al., 1993). Palmquist (1995) observed that addition of cottonseed long fibre decreased fibre digestibility because it increased the pool size of undigested fibre in the rumen. In the present study, both in situ and in vitro ruminal degradation of DM and CP were greater for LCSH than for DCSH, which suggests that short linters are more readily degraded in the rumen than are long linters.

The in vitro acid-pepsin digestion at $39^{\circ} \mathrm{C}$ for $24 \mathrm{~h}$ provides an estimate of the amount of rumen by-pass protein digested in the small intestine (McNiven et al., 2002; Mesgaran and Stern, 2005). Mesgaran (2005) observed that the post-rumen disappearance of protein from barley grains could reach $28 \%$, which is comparable to the value obtained for CLR in the present study. This finding suggests that CLR feed could be a potential source of easily digested rumen by-pass protein.

\section{Gas production kinetics and fermentation end products}

In the present study, gas production was higher for CLR than for the other two CSBPs. This difference is possibly a result of the presence of highly fermentable organic matter in CLR, which would agree with its apparent high in vitro degradability. Gas production has also been reported to be more affected by digestible energy content (e.g., the presence of starch and sugars) than by protein or fat content (Abate, 1980), and high degradable $\mathrm{N}$ compounds have been reported to decrease gas production to some extent (Krishnamoorthy et al., 1995). In the present study, a faster degradation rate was observed for CLR than for either LCSH or DCSH. No apparent differences were observed for ammonia $\mathrm{N}$ in the three CSBPs. We speculated that cottonseed hull-associated protein in LCSH might not be a readily degraded form for rumen microorganisms, and that the high fat content could depress the degradation of the high amount of cottonseed kernel associated protein found in CLR.

The products of the anaerobic microbial fermentation of complex carbohydrates in the rumen include the predominant VFAs, acetate, propionate and butyrate. These are readily absorbed and assimilated as a nutrient source by the host ruminant; in fact, ruminants depend on VFAs for up to $80 \%$ of their maintenance energy requirements (Bergman, 1990). In the present study, total VFA production was markedly lower for DSCH than for CLR, which might be a consequence of the presence of higher amounts of hull associated structural fibre in DCSH than in CLR. Acetate is a necessary component for the formation of milk fat, while propionate is used for glucose production through hepatic gluconeogenesis and is needed for synthesis of milk lactose. A relatively low molar proportion of acetate and a remarkably high molar proportion of propionate occurred with CLR metabolism, which suggested that inclusion of CLR in the diet could serve as a supply of glucogenic precursors in the rumen for glucose production in the host animal.

Methane production in the rumen is an energetically wasteful process. Approximately $6 \%$ of dietary gross energy intake is lost into the atmosphere as $\mathrm{CH}_{4}$ (Holter and Young, 1992; DeRamus et al., 2003). This $\mathrm{CH}_{4}$ in turn contributes to climatic change and global warming (Johnson and Johnson, 1995), as $\mathrm{CH}_{4}$ traps outgoing terrestrial infrared radiation 20 times more effectively than does $\mathrm{CO}_{2}$. Interestingly, although the molar proportion of $\mathrm{CO}_{2}$ and $\mathrm{CH}_{4}$ did not statistically differ when DCSH and LCSH were tested in the present study, comparatively higher $\mathrm{CO}_{2}$ and lower $\mathrm{CH}_{4}$ proportions were observed with CLR.

Long-chain fatty acids have been shown to decrease fibre digestibility and acetate production and to suppress methane production (Getachew et al., 2004; Getachew et al., 2005). The supplementation of whole cottonseed to dairy cows that are offered a forage and cereal diet resulted in a long term reduction in $\mathrm{CH}_{4}$ emissions, which might be caused by an overall increase in dietary fat content (Dohme et al., 2001; Grainger, 2010). Thus, the very high fat content 
of $268.7 \mathrm{~g} / \mathrm{kg}$ DM (Table 1) could explain why a comparatively high depression of $\mathrm{CH}_{4}$ occurred when CLR was used as a feed. In summary, the products of delinted cottonseed hulls can be defined as roughage with a low crude protein and very high fibre content, when compared to feeds consisting of conventional linted cottonseed hulls. The cottonseed linter residue can provide a ME content of $13.29 \mathrm{~kJ} / \mathrm{kg} \mathrm{DM}$, which is almost twice that of delinted cottonseed hulls and conventional linted cottonseed hulls. Both in situ and in vitro digestibility results indicated that cottonseed linter residue could be regarded and/or defined as an energy and protein concentrate for ruminant animals that would be expected to generate comparatively less greenhouse gas due to its high fat content.

\section{ACKNOWLEDGEMENTS}

We appreciate the support of the National Key Basic Research Program of China (Project No: 2011CB100801) and National Natural Science Foundation (Project No. 31072054).

\section{REFERENCES}

Abate, A. 1980. In vitro estimation of the energy content of some feeds commonly fed to livestock in Kenya. East Afr. Agric. Forest. J. 45:255-260.

AOAC. 1999. Official methods of analysis, 16th edn. Association of Analytical Chemists, Washington DC, USA.

Belasco, I. J. 1956. The role of carbohydrates in urea utilization, cellulose digestion and fatty acid formation. J. Anim. Sci. 15: 496-508.

Bergman, E. N. 1990. Energy contribution of volatile fatty acids from the gastrointestinal tract in various species. Physiol. Rev. 70:567-590.

Bertrand, J. A., T. Q. Sudduth, A. Condon, T. C. Jenkins and M. C. Calhoun. 2005. Nutrient content of whole cottonseed. J. Dairy Sci. 88:1470-1477.

Cherry, J. R. 1983. Cotton seed oil. J. Am. Oil Chem. Soc. 60: 360-367.

Chriyaa, A., K. J. Moore and S. S. Waller. 1997. Browse foliage and annual legume pods as supplements to wheat straw for sheep. Anim. Feed Sci. Technol. 62:85-96.

Coppock, C. E., J. K. Lanham and J. I. Home. 1987. A review of the nutritive value and utilization of whole cottonseed, cottonseed meal and associated by-products by dairy cattle. Anim. Feed Sci. Technol. 18:89-129.

Coppock, C. E., J. R. Moya, J. W. West, D. H. Nav, J. M. Labore and C. E. Gates. 1985. Effect of lint on whole cottonseed passage and digestibility and diet choice on intake of whole cottonseed by Holstein cows. J. Dairy Sci. 68:1198-1206.

DeRamus, H. A., T. C. Clement, D. D. Giampola and P. C. Dickison. 2003. Methane emissions of beef cattle on forages efficiency of grazing management systems. J. Environ. Qual. 32:269-277.

Dohme, F., A. Machmueller, A. Wasserfallen and M. Kreuzer.
2001. Ruminal methanogenesis as influenced by individual fatty acids supplemented to complete ruminant diets. Lett. Appl. Microbiol. 32:47-51.

Fadel, J. G. 1999. Quantitative analyses of selected plant by-product feedstuffs, a global perspective. Anim. Feed Sci. Technol. 79:255-268.

Garleb, K. A., G. C. Fahey, Jr. S. M. Lewis, M. S. Kerley and L. Montgomery. 1988. Chemical composition and digestibility of fiber fractions of certain by-product feedstuffs fed to ruminants. J. Anim. Sci. 66:2650-2662.

Getachew, G., G. M. Crovettob, M. Fondevilac, U. Krishnamoorthyd, B. Singhe, M. Spangherof, H. Steingassg, P. H. Robinsona and M. M. Kailasd. 2002. Laboratory variation of $24 \mathrm{~h}$ in vitro gas production and estimated metabolizable energy values of ruminant feeds. Anim. Feed Sci. Technol. 102:169-180.

Getachew, G., P. H. Robinson, E. J. DePeters and S. J. Taylor. 2004. Relationships between chemical composition, dry matter degradation and in vitro gas production of several ruminant feeds. Anim. Feed Sci. Technol. 111:57-71.

Getachew, G., P. H. Robinson, E. J. DePeters, S. J. Taylor and D. D. Gisi, G. E. Higginbotham and T. J. Riordan. 2005. Methane production from commercial dairy rations estimated using an in vitro gas technique. Anim. Feed Sci. Technol. 123-124:391402.

Grainger, C., R. Williams, T. Clark, G. Wright and R. J. Eckard. 2010. Supplementation with whole cottonseed causes longterm reduction of methane emission from diary cows offered a forage and cereal grain diet. J. Dairy Sci. 93:2612-2619.

Hale, W. H., C. Lambeth, B. Theurer and D. E. Ray. 1963. Digestibility and utilization of cottonseed hulls by cattle. J. Anim. Sci. 29:773-776.

Harvatine, D. I., J. L. Firkins and M. L. Eastridgea. 2002. Whole linted cottonseed as a forage substitute fed with ground or steam-flaked corn digestibility and performance1. J. Dairy Sci. 85:1976-1987.

Holter, J. B. and A. J. Young. 1992. Methane production in dry and lactating dairy cows. J. Dairy Sci. 75:2165-2175.

Hsu, J. T., D. B. Faulkner, K. A. Garleb, R. A. Barclay, Jr., G. C. Fahey Jr. and L. L. Berger. 1987. Evaluation of corn fiber, cottonseed hulls, oat hulls and soybean hulls as roughage sources for ruminants. J. Anim. Sci. 65:244-255.

INRA. 1988. Alimentation des bovins, ovins et caprins. Institut Nationale de la Recherche Agronomique, Paris, France.

Johnson, K. A. and D. E. Johnson. 1995. Methane Emissions from cattle. J. Anim. Sci. 73:2483-2492.

Krishnamoorthy, U., H. Soller, H. Steingas and K. H. Menke. 1995. Energy and protein evaluation of tropical feedstuffs for whole tract and ruminal digestion by chemical analyses and rumen inoculum studies in vitro. Anim. Feed Sci. Technol. 52:177188.

Kromer, G. W. 1977. In glandless cotton: its significance, status, and prospects. Proceedings of a conference. Dallas, TX, Agricultural Research Service, US Department of Agriculture, p. 1.

Lee, C. F., R. H. Buu, Y. M. Shy and M. C. Chen. 1991. The nutritive value of pangola grass A253 at different stages of growth. Taiwan Livest. Res. 24:59-65 (in Chinese with English abstract). 
Lee, M., S. Y. Hwang and P. W. Chiou. 2000. Metabolizable energy of roughage in Taiwan. Small Rumin. Res. 36:251-259.

McNiven, M. A., E. Prestlokken, L. T. Mydland and A. W. Mitchell. 2002. Laboratory procedure to determine protein digestibility of heat-treated feedstuffs for dairy cattle. Anim. Feed Sci. Technol. 96:1-13.

Menke, K. H. and H. Steingass. 1988. Estimation of the energetic feed value obtained from chemical analysis and in vitro gas production using rumen fluid. Anim. Res. Dev. 28:7-12.

Mesgaran, D. M. and M. D. Stern. 2005. Ruminal and postruminal protein disappearance of various feeds originating from Iranian plant varieties determined by the in situ mobile bag technique and alternative methods. Anim. Feed Sci. Technol. 118:31-46.

Moreira, V. R., L. D. Satter and B. Harding. 2004. Comparison of conventional linted cottonseed and mechanically delinted cottonseed in diets for dairy cows. J. Dairy Sci. 87:131-138.

National Research Council. 1989. Nutrient requirements of dairy cattle. 6th rev. edn. Natl. Acad. Sci. Washington, DC, USA. 157.

Oltjen, R. R., D. A. Dinius and H. K. Goering. 1977. Performance of steers fed crop residues supplemented with nonprotein nitrogen, minerals, protein and monensin. J. Anim. Sci. 45:1442-1452.

Ørskov, E. R. 1975. Manipulation of rumen fermentation for maximum food utilization. World Rev. Nutr. Diet. 22:152-182.

Ørskov, E. R. and I. McDonald. 1979. The estimation of protein degradability in the rumen from incubation measurements weighted according to rate of passage. J. Agric. Sci. (Camb) 92:499-503.
Palmquist, D. L. 1995. Digestibility of cotton lint fiber and whole oilseeds by ruminal microorganisms. Anim. Feed Sci. Technol. 56:231-242.

Robinson, P. H., G. Getachew and E. J. De Peters. 2001. Influence of variety and storage for up to 22 days on nutrient composition and gossypol level of Pima cottonseed (Gossypium spp.). Anim. Feed Sci. Technol. 91:149-156.

SAS. 1999. Statistical analytical system (SAS) users guide: statistics, version 8.2. Statistical Analysis Institute, Cary, NC. USA.

Sullivan, J. L., J. T. Huber, R. L. Price and J. M. Harper. 1993. Comparison of digestibility, nutritive value, and storage characteristics of different forms of cottonseed in diets fed to lactating dairy cows. J. Anim. Sci. 71:2837-2842.

The Ministry of Agriculture of the People's Republic of China 2010. China Agricultural Yearbook in 2009. China Agriculture Press, Beijing (in Chinese).

Tilley, J. M. A. and R. A. Terry. 1963. A two stage technique for the in vitro digestion of forage crops. J. Br. Grassland Soc. 18: 104-111.

Van Soest, P. J., J. B. Robertson and B. A. Lewis. 1991. Methods for dietary fiber, neutral fiber, and nonstarch polysaccharides in relation to animal nutrition. J. Dairy Sci. 74:3583-3597.

Verdouw, H., C. J. A. Van Echteld and E. M. J. Dekkers. 1978. Ammonia determination based on indophenol formation with sodium salicylate. Water Res. 12:399-402.

Zhang, D. F. and H. J. Yang. 2011. In vitro ruminal methanogenesis of a hay-rich substrate in response to different combination supplements of nitrocompounds, pyromellitic diimide and, 2-bromoethanesulphonate. Anim. Feed Sci. Technol. 163:20-32. 